\title{
AtTItUdes TOWARDS AND EXPERIENCE OF EMPLOYMENT EQUITY
}

Authors:

Rudolf M. Oosthuizen

Vasantha Naidoo ${ }^{1}$

\section{Affiliations:}

${ }^{1}$ Department of Industrial and Organisational

Psychology, University of

South Africa, South Africa

\section{Correspondence to:}

Rudolf Oosthuizen

email:

oosthrm@unisa.ac.za

\section{Postal address:}

Department of Industrial and Organisational

Psychology, University of South Africa, PO Box 392,

UNISA 0003, South Africa

Keywords:

attitudes; experience; employment

equity; affirmative

action; hermeneutic phenomenological method

\section{Dates:}

Received: 04 June 2009

Accepted: 18 Aug. 2010

Published: 23 Nov. 2010

How to cite this article: Oosthuizen, R.M., \& Naidoo, V. (2010). Attitudes towards and experience of employment equity. SA Journal of Industrial Psychology/SA Tydskrif vir Bedryfsielkunde, 36(1), Art. \#836, 9 pages. DOI: 10.4102/ sajip.v36i1.836

\section{This article is available} at: http://www.sajip.co.za

(C) 2010. The Authors. Licensee: OpenJournals Publishing. This work is licensed under the Creative Commons Attribution License.

\section{ABSTRACT}

Orientation: The demography of the South African work force has changed considerably since the implementation of Employment Equity Act 55 of 1998. There is no clarity in the literature on employees' attitudes towards and experiences of employment equity (EE).

Research purpose: The purpose of this research was to contribute to the EE debate by qualitatively identifying and exploring employees' attitudes towards and experiences of EE in the South African work context.

Research design, approach and method: Twenty-one organisations were included in the study and 105 interviews conducted.

Main findings: The results indicated that employees at management level perceived government as an EE 'watchdog'. Furthermore, reverse discrimination and racism were demarcated as the main experience of non-management employees. For previously disadvantaged employees, the main concerns were lack of training and development, whereas for the non-previously disadvantaged the primary concerns were reverse discrimination, racism and victimisation.

Pratical/managerial implications: Future research may be that the results can benefit from contrasting, (1) the perspectives of previously disadvantaged management versus previously advantaged management to (2) the perspectives of previously disadvantaged non-management versus previously advantaged non-management. Furthermore, it will be valuable to include other industries in the private and public sector in future samples.

Contribution/value-add: The contribution of the research is building and/or supporting the current knowledge base of employees' attitudes towards and experiences of EE in the South African work context. Proactive measures should be taken to ensure that the majority of previously disadvantaged and the non-previously disadvantaged groups benefit from EE legislation. The introduction of holistic human resource management practices that complement target setting, could overcome the stumbling blocks currently being experienced in the effective implementation of EE.

\section{INTRODUCTION}

Part of the transformation agenda for South Africa after the 1994 elections, was the transformation of all organisations to make them representative of all South African citizens (Denton \& Vloeberghs, 2003; Leonard \& Grobler, 2006). The rationale for introducing Employment Equity Act 55 of 1998 was to enforce transformation on the basis that organisations would not empower sufficient numbers of Black employees of their own free will (Leonard \& Grobler, 2006). Although there is evidence of transformation of the work force, the implementation of the Employment Equity Act is often reduced to a question of legal compliance (Leonard \& Grobler, 2006). A consequence of the scepticism and cynicism of business leaders is that the attitudes and experiences of employees affected by the implementation of these transformational laws are often not taken into consideration.

There is no clarity in the literature on employees' attitudes towards and experiences of EE. According to one line of thought, both beneficiaries and nonbeneficiaries have negative attitudes towards and experiences of EE and these are based on divisive sentiments. Beneficiaries may fear tokenism and marginalisation, being victims of White manipulation or being sold out, when appointed in designated positions. On the basis of the 'stigmatisation' argument (Heilman, Block \& Stathatos, 1997), professional employees, who believe in individual merit, also dislike the labels 'incompetence' and 'less qualified', which are associated with EE. White employees, however, not only question the political and ethical legitimacy of $\mathrm{EE}$, but also fear retribution or revenge from previously disadvantaged groups, loss of standards, punitive taxation and limitation of their career opportunities (De Beer \& Radley, 2000; Leonard \& Grobler, 2006). EE has also sometimes been perceived as racism, unfair treatment and reverse discrimination (Denton Vloeberghs, 2003; $\mathrm{Ng} \&$ Burke, 2004). On the basis of this line of thought, it can be argued that beneficiaries and nonbeneficiaries may find a 'common enemy' in EE that will help them to avoid dealing with the divisive sentiments or underlying racial or gender polarisation despite the fact that the sources of their dissatisfaction with EE are substantively different.

Another line of thought is based on the 'theory of self-interest', whereby beneficiaries of EE tend to be positive towards such programmes (Tougas, Beaton \& Veilleux, 1991). Previous research, for instance, found that women and minority groups in general have more positive attitudes towards EE than White men (Ng \& Burke, 2004). An implication of this finding is that the different attitudes and experiences may lead to renewed polarisation and distrust among employees, leading to higher staff turnover, especially amongst those from designated groups (Thomas, 2002). In a South African study, Thomas (2002) found that the so-called 'job-hopping' of Black managers cannot only be ascribed to higher salaries or better perks, but also to issues relating to not fitting into historically established corporate cultures. 
The demography of the South African work force has changed considerably since the implementation of the Employment Equity Act. This has led to a strong emphasis on the management of diversity (De Beer \& Radley, 2000). In order to manage a diverse work force, it is necessary to address the attitudes of employees (Denton \& Vloeberghs, 2003). The purpose of this research is to contribute to the EE debate by qualitatively identifying and exploring employees' attitudes towards and experiences of EE in the South African work context.

\section{Employment equity}

The concept 'employment equity' has occupied centre stage in world business economic debates for as long as the concep 'workforce' has existed (Erasmus, Loedolff, Mda \& Nel, 2007). The ultimate purpose of these debates has been to restore human dignity in the world of work. Many human indignities were experienced in the workplace, because employees were seen as desperate people who could dance to any tune set by the employer (Nevin, 2008).

Foremost in understanding the background to $\mathrm{EE}$ is the implementation of Employment Equity Act 55 of 1998 in order to fulfill a constitutional mandate to veto discrimination in the workplace and promote affirmative action (AA) measures which are a more valued input into the job selection process. The Act defines the designated groups, or recipients of EE opportunities, as all Black employees, women and the physically challenged. The term 'Black' is applicable in the Act to African people, Coloured people and Indian people and recently also includes South African-born Chinese people (Nevin, 2008).

EE is defined as the employment of individuals in a fair and nonbiased manner (Bendix, 2010). $A A$ refers to programmes designed to ensure proportional representation of employees and undo the results of past discrimination. However, the latter definition may be viewed as somewhat problematic because it does not explicitly acknowledge the assumption that those being considered for proportional representation are all equally qualified for certain positions (Saha, O'Donnell, Patel \& Heneghan, 2008). It should also be mentioned that the terms 'employment equity' and 'AA' are sometimes used interchangeably, although they are two different, but related concepts (Mason, Williams \& Cranner, 2009; Portnoi, 2003).

According to Nel, Kisten, Swanepoel, Erasmus and Poisat (2008), Employment Equity Act 55 of 1998 stipulates that employers may not refuse to reward individuals on the basis of the inputs employers may deem unfavourable. For example, an employer may see an individual's sexual orientation as an unfavourable input into the employment relationship and, on those grounds, refuse to promote or grant them an annual increase. The Act attempts to regulate such unjust behaviour. In addition to the role legislation plays in upholding principles of equity, there is the practice in many business organisations of promoting and rewarding people who bring valued inputs into the workplace. Such inputs include skills, expertise, training and technological know-how, as well as sound managerial and interpersonal skills. As such, the more such valued inputs one can offer, the higher one's allocations and rewards are likely to be.

$\mathrm{Nel}$ et al. (2008) further postulate that the principle of distribution on the basis of equity may raise concern about the justice perceptions of the parties concerned of the tripartite employment relationship (viz. government, employers and employees) in two respects. The first concern relates to whether all parties agree that equity is the most reasonable and fairminded basis upon which to make reward allocations and resource distributions and conduct performance appraisals. The second possible concern relates to what each of the parties considers as valued inputs and outputs. For example, employers may feel that verbal recognition or 'an employee-of-the-month' type award is a valued outcome for a job well done, whereas employees may perceive such rewards to be worthless and may value an incentive or bonus cheque more highly.
Given such concerns and differences in perceptions of fairness and equity, it is evident that South African organisations face many challenges in implementing the Employment Equity Act effectively and efficiently. The critical questions are thus whether business organisations can navigate these stormy waters and how corporate entities should manage effective communication efforts in support of equitable change management strategies.

Research conducted by Booysen (2007) and Selby and Sutherland (2006) reported that it is a challenge for business organisations to create working environments in which employees experience job satisfaction through fair employment practices, while also optimally achieving company objectives. Figure 1 indicates the reasons for the high erosion rates in the implementation of EE practices. These challenges indicate the need to address prevalent and persistent unfair discrimination exclusionary measures which are characteristic of both South African business organisations and businesses in the international arena (Kilian, Hukai \& Mcarty, 2005).

These realities emphasise the need for organisations to communicate the underlying purpose of the EE policy and the need to involve the entire workforce in this transformational initiative. The facts of stereotyping racial groups and misunderstandings about the real intentions of EE emphasise the need to address the sociohistorical context of Employment Equity Act 55 of 1998 in any related communication strategy (Leonard \& Grobler, 2006).

$\mathrm{EE}$ is one of the most pressing challenges facing South African managers. Many business organisations underestimate the process of instituting EE on different organisational procedures, practices and roles, as well as on organisations' climate and culture (Nienaber, 2007). The search for South African managers implies not only a deliberate effort on their part, but also having the necessary tools to effectively and professionally manage the change process. Simply stated, in their endeavours to implement EE efficiently, management need to have a shared vision of what the business organisation ultimately wants to achieve through its EE policy. Management also need to consider whether the business organisation has the capacity to design and lead the process of creating fair, equitable and tangible actions that showcase their commitment to EE (Nienaber, 2007).

In referring to non-management employees, sustainable change depends on active engagement in partnerships of employers, employees and unions in workplaces in identifying equity issues and agreeing on response plans to address them. EE needs to be just, fair and impartial because it concerns employees and their jobs (Doyle-Bedwell, 2008). It is purported that previously disadvantaged groups (race-based beneficiaries and White women) dislike the labelling associated with EE measures, such as being sell-outs, being sold out, being victims of White manipulation, victimisation, tokenism, marginalisation and special EE status. These individuals typically believe in career advancement on the basis of individual merit. Conversely, nonpreviously disadvantaged groups (i.e. White men) fear revenge/

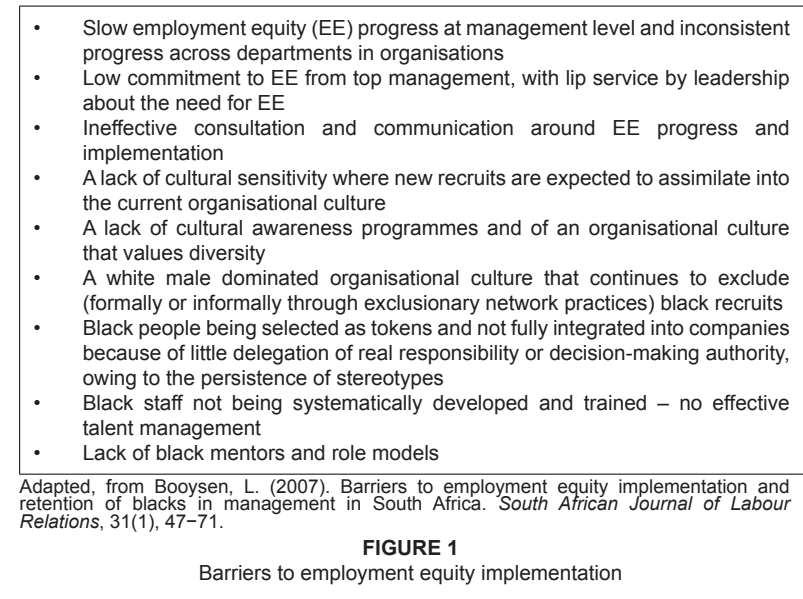


TABLE 1

Sample breakdown by race, gender and occupational category: Individual interviews

\begin{tabular}{|c|c|c|c|c|c|c|c|c|c|}
\hline \multirow[b]{2}{*}{ Consolidated organisation information } & \multicolumn{6}{|c|}{ Previously disadvantaged groups } & \multicolumn{2}{|c|}{$\begin{array}{c}\text { Non-previously } \\
\text { disadvantaged groups }\end{array}$} & \multirow[b]{2}{*}{ Total } \\
\hline & $\mathrm{CM}$ & $\mathrm{CF}$ & IM & IF & AM & $\mathrm{AF}$ & WM & WF & \\
\hline Employees at management level & 2 & 4 & 3 & 1 & 6 & 3 & 13 & 8 & 40 \\
\hline Nonmanagment employees & 5 & 5 & 2 & 6 & 12 & 17 & 10 & 8 & 65 \\
\hline Total & - & - & - & - & - & - & - & - & 105 \\
\hline
\end{tabular}

Key: CM, Coloured males; CF, Coloured females; IM, Indian males; IF, Indian females; AM, African males; AF, African females; WM, White males; WF, White females.

retribution from nonwhites, loss of standards, punitive taxation and nationalisation and they tend to question the political and ethical legitimacy of the EE policy (Esterhuizen \& Martins, 2008).

\section{RESEARCH DESIGN}

\section{Research approach}

The research approach was to conduct a hermeneutic phenomenological study, by addressing EE questions concerned with fostering an understanding of the meaning and experiences in people's work lives and social worlds (Fossey, Harvey, McDermott \& Davidson, 2002). As part of this study, industrial and organisational psychology honours students conducted an exploratory, qualitative research project. The students studied the relatively unexplored area of attitudes towards and experiences of EE (Field \& Morse, 1985).

The researchers assumed that the respondents' subjective attitudes and experiences were real and worthy of in-depth study and that engaging their perspectives was critical to answering the relevant research questions (Ely, Anzul, Friedman, Garner \& Steinmetz, 1990; Terre Blanche \& Durrheim, 2002). The researchers were interested in employees' subjective attitudes towards and experiences of EE and the manner in which they expressed these attitudes and experiences. This was vital in understanding the meanings that people attach to their attitudes towards and experiences of EE in the workplace (Ramgoolam, 2005).

The hermeneutic phenomenological perspective was expected to yield rich and detailed descriptions of EE issues (Ramgoolam, 2005). This approach is based on the following steps, (1) the data were subjected to an initial, preliminary and holistic assessment, (2) certain themes were generated from the data, (3) the data were coded, (4) the body of the text was broken down into meaningful pieces that were labelled, (5) closer attention was focused on the subtleties and nuances of the meaning inherent in the data, because the original coding might not have captured these meanings adequately and (6) the actual written account of the study was then reviewed in order to remedy any weaknesses in the interpretation (Guba \& Lincoln, 1994; Neuman, 1994, Ramgoolam, 2005).

\section{Strategies employed to ensure quality of data}

In order to increase the trustworthiness and to verify the findings of the present study, the following sections are presented in such a way that other researchers will be able to follow the investigative process. This will enable the reader to draw similar conclusions on the basis of the data gathered, the perspective adopted and the research situation. Qualitative researchers prefer the term 'trustworthiness' to the terms 'reliability' and 'validity' (Guba \& Lincoln, 1982). Trustworthiness has four elements, namely credibility, transferability, dependability and confirmability. Verification in inductive research refers to the mechanisms used during the research process to incrementally contribute to the rigour of the study (Morse, Barrett, Mayan, Olson \& Spiers, 2002). Specific methodological strategies for demonstrating qualitative rigour include an audit trail and confirming the results with research informants (Guba, 1981; Guba \& Lincoln, 1982; Lincoln \& Guba, 1985; Pietersen, 2007).

\section{Research method}

\section{Research participants}

The study's population comprised all South African organisations employing 50 or more people or with specified financial turnovers requiring them to comply with EE legislation (Department of Labour, 2002; Thomas, 2003). Twenty-one organisations were targeted for inclusion in the study. The sample was determined by industrial and organisational psychology honours students in terms of convenience, expert judgment and other types of conscious researcher selection (McGown, 1979). It is acknowledged that such selection could contain elements of subjectivity. Other criteria taken into account in targeting organisations were geographic location and industry. The profile of organisations, according to industry sector, was as follows:

- banking and financial services (four)

- mining (one)

- retail (two)

- manufacturing (two)

- government (seven)

- entertainment (three)

- construction (one)

- health (one).

\section{Sampling}

The researchers applied convenient employee sampling in the study (Bailey, 1987). This is a sample based on the relevant employees who were available at the time. The researchers were interested in the detailed, in-depth analysis of a smaller group (Ramgoolam, 2005; Terre Blanche \& Durrheim, 2002). English is the official language of choice in the target organisations in South Africa. Employees who have had experiences relating to the phenomenon to be researched' (Kruger, 1988, p. 150) and who were able to communicate in English were included in the sample. The purpose of this was to increase the accuracy of the information (Pietersen, 2007). Table 1 details the demographic breakdown of the sample.

\section{Research procedure}

The purpose of the study was explained in broad terms and employees at management and non-management level from both previously disadvantaged and non-previously disadvantaged groups were invited to share their experiences of EE under investigation. Individual interviews (105) were conducted by honours students in the different organisations over a four-month period as part of their EE research project in employment relations. The researchers provided detailed interview instructions to the interviewers to ensure that the interview process was standardised. In determining the duration of the interview, the interviewers were guided by the respondents. The interviews lasted 30 minutes to one hour. The interviewees were assured of the confidentiality of the research data obtained. Permission was obtained beforehand from the respondents for note taking and sound recording during the interviews. The following question was posed: 'What is your personal story in terms your experience of EE in the workplace?' If necessary, this question was probed by means of elaboration and further explanation (Pietersen, 2007). 


\section{Data analysis}

As recommended by several authors (Charmaz, 1995; Ramgoolam, 2005; Strauss \& Corbin, 1990; Terre Blanche \& Durrheim, 2002), the researchers applied the following steps to analyse the data.

Step 1: The protocols were transcribed after the interviews while the information was still fresh in the minds of the interviewers.

Step 2: A preliminary understanding of the data was reached by studying the relevant texts, making initial analytical notes and brainstorming.

Step 3: Themes were generated from the data by organising the data through a process of line-by-line analysis, because this was deemed most generative for the research purposes.

Step 4: The data were coded by marking different sections thereof as being instances of and relevant to one or more themes. When coding data, the body of text was broken down into meaningful sections and was labelled accordingly.

Step 5: The analytical process was elaborated on by paying closer attention to the subtleties and nuances of the meaning inherent in the data.

Step 6: The data were interpreted.

\section{RESULTS}

Consolidated themes that emerged from individual interviews with employees at management and non-management level from previously disadvantaged and non-previously disadvantaged groups are presented below. The frequency counts were derived from the analysis of data elicited during the individual interviews with members of the sample. In every case, the frequency and corresponding proportion of the relevant sample are provided in brackets.

\section{Employees at management level}

The themes that emerged most frequently from the attitudes and experiences of employees at management level in terms of EE were government's role of 'watchdog' ( $f=10,25 \%)$, lack of skills and experience $(f=9,22.5 \%)$ and EE staff being incompetent $(f=8,20 \%)$. The themes that emerged less frequently (i.e. moderately) were the poor management of diversity $(f=6,15 \%)$ the negative expectations of designated groups $(f=5,12.5 \%)$ and poor communication of EE policies $(f=5,12.5 \%)$. The themes of the negative impact on service delivery $(f=4,10 \%)$, genderrelated issues $(f=3,7.5 \%)$ and Black economic empowerment $(f$ $=3,7.5 \%$ ) emerged to a lesser extent. Themes with a frequency of eight or more are discussed in more detail. Direct quotes from the interviews are reported to substantiate the results.

\section{Theme 1: Government's role of 'watchdog'}

Over-regulation of the labour market, coupled with government's role as 'watchdog', result in a decrease in overseas investments and entrepreneurial initiatives, especially in the medium and small business sectors (Dickman, 1998). Responses from employees at management level concerning EE included the following:

They introduce legislation to bring about equal employment in the workplace, focusing particularly on previously disadvantaged staff. They try to eradicate discrimination, promote fairness and labour peace by implementing affirmative action measures. They see it as a form of 'corrective action' against the apartheid regime to promote equal employment opportunities for the mass population who were previously disadvantaged in respect of holding or attaining senior management or executive positions in the organisation.

(Respondents)

The study revealed that some employees at management level believed that EE is simply a political imperative they are compelled to fulfill. However, it is evident in South African organisations that they are merely complying with the legislation. As a result, they do not invest much in the rationale and merely comply with legislation to keep the ball of EE rolling. This sentiment is exhibited in the following statement:

Organisations are only complying with the legislation. Many irregularities are found in the workplace, and this leads to employment equity not achieving its intended objective.

(Respondent)

The general view is that management has to comply with EE, without any choice on how, what and when they can do things. They believe that they are wasting time by spending so much time coaching people, and they cannot achieve results immediately:

Management complies with the legislation, because they always involve employees on the ground where they come together and analyse the progress which has been made by the organisation in terms of putting some measures in place in order to enhance equity in the workplace.

(Respondent)

The implementation of the legislation and the severe consequences for organisations that fail to comply with legislation, have forced managers into 'compliance mode'. For many organisations, the need to comply has overshadowed the need to transform because of the financial implications that accompany noncompliance seeing that organisations are fined if they do not comply with the legislation (Jongens, 2006).

\section{Theme 2: Lack of skills and experience}

The attitude of employees at management level towards EE is that it is a sound strategy that seeks to achieve equity in the workplace in South Africa, especially when considering the country's history. This is more relevant in the current predicament facing managers, namely the country's skills shortage, as exemplified in the crises experienced at Eskom, the energy utility, during the course of 2009 when power failures and load shedding occurred throughout South Africa:

This is proof that we are experiencing a skills shortage in South Africa. You often find people who are in positions that they do not qualify for - we call this a skills mismatch.

(Respondent)

EE appointees lack the necessary skills and are appointed to either fill quotas or for window dressing. EE implies inferiority and stigmatises its beneficiaries; EE decisions are based on preferential treatment instead of merit (Vermeulen \& Coetzee, 2006):

Black people are being compensated for their qualifications and experience at work, although sometimes the system is being abused by the powers because of comradeship under the guise of employment equity in the sense that unqualified people fill certain positions where they are unable to deliver efficiently. Owing to employment equity, the country is experiencing a skills drainage. Skilled whites are leaving as there are no chances for advancement.

(Respondent)

EE for employees at management level is necessary, but respondents do believe that it is adversely affecting the business:

There are no black skilled people out there.

(Respondent)

Central to this is the issue of training and skills development. Chapter 3 of Employment Equity Act 55 of 1998 states that AA measures should include retaining and developing people from designated groups and implementing appropriate training measures, including measures in terms of an Act of Parliamen providing for skills development. As for the matter of EE forcing White people out of the country, all the respondents agreed that this was a reality:

I am a white male who resigned less than a month ago and want to explore new opportunities after being in government for approximately 30 years. I am concerned that there may not be a future for me in South Africa and will even consider opportunities abroad. In my opinion, South Africa is no longer a country for 
white South Africans, because we are being treated unfairly. Only black people will benefit from this and will be able to survive in this country. This is no longer a place for White people, and this is made clear to us in many ways, not only in the workplace.

(Respondent)

Senior managers believe that EE is imperative, but organisations also need to consider the way in which they are performing and the widely recognised skills shortage in South Africa:

Production decreases because the most suitable employees are not hired or promoted. Most black qualified employees lack the necessary experience, especially in the professional disciplines.

(Respondent)

In addition to the skills shortage, the so-called 'brain drain' of South Africans of all races is making it more difficult for organisations to perform and to find suitable staff. Managers indicated that, at times, these considerations were more important than ensuring that a person from a previously disadvantaged background is employed.

\section{Theme 3: Employment equity staff is incompetent}

$\mathrm{EE}$ is meant to ensure macro justice (i.e. justice between groups of people), but resistance frequently arises because of concerns about micro justice (i.e. justice for individuals):

The accusations most frequently levelled at employment equity is that it is a form of reverse discrimination, that employment equity appointees are less competent than some other applicants.

(Respondent)

As indicated by this study's respondents, further experiences of EE include the following:

Owing to the pressure in becoming black economic empowerment compliant, the quality of the staff appointed is not only often compromised, in the lack of experience, but also in the total lack of commitment and attitude of the appointee. There is a big element of 'because I am black, I have to be here' and the output levels and quality of work produced are thus often sacrificed.

(Respondent)

There is an underlying assumption that EE is affecting business results and can be seen in the following quotation:

It is difficult to recruit black people for critical jobs. We are therefore forced to employ people who are incompetent, and this affects business performance.

(Respondent)

The collective view appears to be that only White people are competent and Black people are not. Qunta notes that the 'lowering of standards' argument is underlined by the negative assumption that 'African people are generally not as capable as White people' (Qunta 1995, p. 25). It may be correct to state that the previously disadvantaged group lacks the competencies and experience to deliver immediately on the job and could be due to the fact that the previously disadvantaged groups were formerly denied opportunities in these jobs.

\section{Non-management employees}

The themes that emerged most frequently from researching attitudes towards and experiences of non-management employees in terms of EE, differed substantially from the employees on management level. These themes included, (1) reverse discrimination and racism $(f=18,27.70 \%),(2) \mathrm{EE}$ as a numbers game $(f=11,16.92 \%)$ and (3) lack of implementation and alignment of EE $(f=10,15.38 \%)$. The themes that emerged less frequently (i.e. moderately) were (1) window-dressing $(f=$ $8,12.30 \%)$, (2) lack of training and experience $(f=8,12.30 \%)$, (3) inequity of salaries and benefits $(f=8,12.30 \%)$, (4) poor communication $(f=6,9.23 \%)$, (5) decline of standards $(f=6$, $9.23 \%)$ and (6) no benefit at all from EE for disabled people $(f=6$, $9.23 \%)$. Gender issues $(f=5,7.70 \%)$, job hopping and skipping $(f$ $=5,7.70 \%)$, lack of management commitment $(f=4,6.15 \%)$ and preferential treatment for race groups $(f=3,4.61 \%)$ emerged to a lesser extent. The themes with a recorded frequency of more than 10 are discussed in more detail. Direct quotes from the interviews are reported to substantiate the results.

\section{Theme 1: Reverse discrimination and racism}

All respondents from the different race groups agreed that EE is a tool to advance Black people. However, this issue of Black advancement has a downside, because it is often considered as reverse discrimination and is a general view held by employees in organisations. A Coloured respondent had the following to say in this regard:

We have become the very thing we despised, 'Whites only' now it is 'Blacks only' and it is justified in the law in the same way. It is actually appalling. This is what I think: do not give the man a job, because he is Black, give him a job because he can do it, regardless of his race.

(Respondent)

Qunta (1995) disagrees with the argument that EE is reverse racism, because the word 'racism' suggests that one group of people is superior to the other. EE policies do not imply that White people are inferior or incapable of performing certain tasks if they are overlooked for certain jobs, but they cannot be alone in benefiting from life's opportunities.

Another Coloured respondent felt that he was stagnating in his current position:

If employment equity had never been implemented, I would be earning more money and would be in a higher position.

(Respondent)

A Black respondent expressed her frustration as follows:

I personally have not benefited. They often say that African females are preferred, but during interviews, African now suddenly also means Coloured and Indian females.

(Respondent)

There has been a problem with designated groups because the demographics in South Africa have been artificially established by influx control and other policies (Bendix, 2007):

This is a challenge in the Western Region and being in the recruitment field, it usually is the case that coloured and Indian people are preferred, because they are the larger population in this region.

(Respondent)

\section{Theme 2: Employment equity is a numbers game}

Non-management employees recognise that EE and AA are concerned with increasing numbers and not adding value and that this does not have a positive impact on the organisation. The findings revealed that there was no consensus between the different designated groups on this issue. According to an information technology consultant

The way employment equity is implemented, leads managers to chase numbers rather than create value by training people.

(Respondent)

An editor added further to this view by stating the following:

There is no vision or plan as far as employment equity is concerned - it is just a question of let's meet the short-term targets.

(Respondent)

Webster and Von Holdt (2005) describe this phenomenon as the 'upward-floating colour bar' where Black employees are promoted to supervisory level, but do not have real authority because White employees have simultaneously been promoted above them.

The opinions expressed are that EE programmes focus on figures only. The so-called 'quota system' depersonalises people and views them as numbers only. According to Qunta (1995), such a focus is not a useful approach to the issue seeing as numbers address only part of the challenge. There should be two major 
criteria for assessing the success of EE and AA, namely numbers and organisational climate. Organisational climate is important for Black and White employees, who should be prepared for transformation processes such as AA. If the organisational climate is favourable, the so-called 'revolving door syndrome' together with 'White fears' should be eliminated. Existing measures of the success of EE are equally vague and largely involve head counting. There is little recognition of the effect EE has on organisations, its processes, productivity, resources and employees (Qunta, 1995).

\section{Theme 3: Lack of implementation and alignment of employment equity}

All the non-management employees who were interviewed indicated that their companies had embarked on a thorough transformation process including all the steps necessary in the process of AA. This research highlighted the difficulties faced by large established organisations in terms of effective implementation of both EE and AA. Some respondents indicated the conundrum of having to maintain productivity while having to comply with legislation. This has been the cause of much debate and consternation in these organisations. Problems such as the existence of systematic discrimination, transformation, questions over leadership, difficulties retaining Black people cropped up repeatedly. The overriding perception of nonmanagement employees was that management at all levels is not totally committed to the process:

Implementation is not done in accordance with the terms and conditions of employment equity and affirmative action, that is, same-job-same pay. The evidence shows that it is implemented effectively in pockets, but not consistently.

(Respondent)

EE is a long-term process that cannot be achieved in 15 years In South Africa's history, many people have been impatient for change to occur more rapidly, but in order to implement change satisfactorily and lastingly, the process cannot be rushed Malaysia succeeded with its EE process over a period of 20 years while experiencing significant economic growth (Walters, 2007). South Africa has been applying EE for only 16 years and lacks economic growth or formal expansion of employment, both of which contribute to the troubled atmosphere wherein EE is being implemented.

\section{One respondent had the following to say:}

I believe employment equity is a good idea in principle, but it is difficult to implement, because I do not believe that large organisations and small to medium-sized businesses are embracing the policy. They see it more of a hindrance than an opportunity to improve capacity and to build the necessary skills for the majority of the population. Employment equity focuses on trying to achieve a balance between previously advantaged and disadvantaged groups by determining areas of direct and indirect discrimination like employment or recruitment politics and procedures. These should be structured in such a way that they promote opportunities for the previously disadvantage groups.

(Respondent)

Other respondents indicated that EE was indeed taking place, but not fast enough because of inconsistencies in units and departments.

\section{Previously disadvantaged groups}

The themes that emerged most frequently from the attitudes and experiences of previously disadvantaged groups in terms of EE were, (1) lack of training and development ( $f=13,19.70 \%)$, (2) unfairness, preferential treatment for African women $(f=12$, $18.18 \%$ ), (3) people with disabilities seldom being included in EE $(f=10,15.15 \%)$ and (4) negative expectations of designated groups $(f=8,12.12 \%)$. The themes that emerged less frequently (moderately) were, (1) tokenism $(f=6,9.10 \%),(2)$ power still with the non-previously disadvantaged group $(f=6,9.10 \%)$ and (3) discrimination $(f=6,9.10 \%)$. Window dressing $(f=5$, $7.60 \%)$, inequity of salaries and benefits $(f=5,7.60 \%)$, poor communication $(f=4,6.10 \%)$, women not involved in decision making $(f=4,6.10 \%)$ and EE has not achieved its intended purposes $(f=4,6.10 \%)$ emerged to a lesser extent. The themes with a recorded frequency of eight or more will be discussed in more detail. Direct quotes from the interviews will be reported to substantiate the results.

\section{Theme 1: Lack of training and development}

A strong view exists amongst respondents that training and development need to be accelerated, because it does not appear to be happening as fast as it should:

More Black people need to be trained and placed in management positions.

(Respondent)

Some of the respondents indicated that they would appreciate training, but that the luxury of having the capacity and time to adequately train individuals was lacking:

They need someone who is already sufficiently skilled to come in and start working.

(Respondent)

In addition, some respondents raised the concern that on occasion, time and effort are devoted to up-skilling previously disadvantaged individuals, but the individuals have subsequently left the organisation:

We trained a Black man to assist in the sales department. Three months down the line, when he had learnt enough, he moved to another company for more money, even though the salary we were paying him was market related and fair.

(Respondents)

An aspect that emerged from the interviews is that training and development are an essential part of effective implementation of EE. South Africa is in a unique position because beneficiaries of AA represent a group that is unfavourably positioned when compared to the rest of the population. This is as a result of imbalances in education, training and experience. It is therefore crucial to take these considerations into account when recruiting previously disadvantaged groups in designated positions.

\section{Theme 2: Unfairness, preferential treatment for African women}

African men contend that they are also the beneficiaries of the intervention of $\mathrm{EE}$, but have realised that African women are experiencing an unfair advantage over designated group members. Women are affirmed even if they do not qualify for the job. According to African men, they always receive preferential treatment in terms of benefits in the workplace, including appointments, promotions, training and performance appraisals, to mention a few. One Coloured female respondent felt that she was 'sitting on the fence' in the workplace. Prior to 1994, she had been considered 'too dark', whereas after 1994, she was considered 'too White' to benefit from EE.

African women argue that they deserve to receive preferential treatment, because they were the most disadvantaged group. They were discriminated against and oppressed by African men in the workplace. One of the respondents, a former female teacher, stated the following:

We were earning less compared to our male counterparts, whereas they were doing the same work and had the same academic qualifications and experience.

(Respondent)

An Indian woman said that she had worked really hard to get to where she is today and that no one respected this, because they regarded it as AA. According to her:

I am really good at my job and want to be judged on my ability and not my skin colour. The issue of fairness has been manipulated and leaves a gap that was supposed to benefit all members, but instead it satisfies the selected few, especially those who were involved in the liberation struggle during apartheid.

(Respondent) 


\section{Theme 3: People with disabilities are seldomly included in employment equity}

Disability appears to be an aspect of EE that has received less attention than other requirements pertaining to the Employment Equity Act 551998 and supports the findings of Thomas and Hlahla (2002). Interviews with employees with disabilities presented the following views: people with disabilities are consistently overlooked in all spheres of the working world. Although AA is supposed to consider people with disabilities, this rarely happens. Jongens (2006) argues that people with disabilities have been ignored in the EE processes. In South Africa the majority of the disabled population is Black.

One respondent said the following:

In our organisation the majority of disabled employees fall into this category, but only two of them are African. Converting a business environment into a disability-friendly environment is often not prioritised. If there were a more proactive and supportive environment for these people, more of them would come forward and life for them would be much easier. A major reason for the lack of people with disabilities in this company is that there are very few job agencies that recruit people with disabilities and only those that apply directly to the company are considered.

(Respondent)

A Black respondent with disabilities also mentioned that management needed to attend workshops on how to treat people with disabilities employed at their companies:

Two blind girls were employed in a communication department as experiential trainees when they applied for the positions of communication officers. They were told that they would not be able to do the job as advertised - they would only be able to do $20 \%$ of it .

(Respondent)

No assessment had been done on these two trainees to prove the above statement. The Black respondent with disabilities felt strongly that provision should be made before such legislation is implemented:

Disabled people are only wanted for administrative or receptionist positions and their qualifications are disregarded as long as their faces are there and adding on the numbers.

(Respondent)

Theme 4: Negative expectations of designated groups

A prevalence of negative expectations about candidates from designated groups was a definite concern raised by employees:

Most of the people who are employed cannot do the work.

(Respondent)

There may be a number of reasons why these candidates cannot do the work, including lack of experience and qualifications. Candidates from designated groups are constantly scrutinised and subjected to the fears and resentment belonging to those who stand to lose promotional opportunities. The resultant overt and covert sabotage of the process, by withholding information from and excluding members of designated groups from formal and informal networks and systems that assist in job progress, are further examples of concerns. According to Qunta (1995, p. 27), 'Black professionals who fail or make mistakes are judged more harshly than their white counterparts'. She went on to say that what is more disturbing is that their failure is used as an indictment of Black people as a whole, whereas the failure of White people is considered on an individual basis.

\section{Non-previously disadvantaged groups}

The themes that emerged most frequently from the attitudes and experiences of non-previously disadvantaged groups in terms of EE were reverse discrimination, racism and victimisation $(f=$ $19,48.71 \%)$ and loss of employment $(f=7,17.94 \%)$. The themes that emerged less frequently (i.e. moderately) were, (1) the brain drain $(f=5,12.82 \%)$ and (2) EE is not applied correctly $(f=3,7.70 \%)$. Themes including, (1) EE are not promoting economic growth, (2) a decline in morale, (3) EE as a vehicle to achieve political aims, (4) stereotypes, such as the 'baas/klaas' relationship, (5) erosion of power and (6) the numbers game, emerged to a lesser extent. A frequency of two was recorded for these themes. The themes with a recorded frequency of five or more will be discussed in more detail. Direct quotations from the interviews will be reported to substantiate the results.

\section{Theme 1: Reverse discrimination, racism and victimisation}

A White respondent strongly agreed that $\mathrm{EE}$ is a form of reverse discrimination:

The White race has been completely shut out, just as it was in the past with Black people. There is no solution. I am white and male, and employment equity creates barriers for me.

(Respondent)

Another White male respondent indicated that he did not discriminate against anyone, because he had still been at school when transformation had occurred at the end of the apartheid era. He perceived that he was being discriminated against and indicated that

A role reversal is taking place.

(Respondent)

He agreed that the discrimination of the past was wrong, but added that

Two wrongs do not make a right.

(Respondent)

Another White man was still positive, even though he had not received the promotion he had expected. He indicated that he had experienced the reversal of discrimination, even if it was to a lesser degree, he had to go on with his life. He said:

I believe that we now have to pay for the sins of our fathers and I always live by the principle live and let live and now I suppose it is $\mathrm{Mr}$ 'Black's' time to live.

(Respondent)

White men in particular are experiencing the effects of EE, because they feel completely ignored and/or sidelined. White men with years of service feel disappointed when they expect promotions and AA appointees from outside their organisations are given the positions. A White manager commented as follows:

I have been a loyal and hardworking employee for 30 years and I am now being moved into another department in the name of transformation. What about my career objectives?

(Respondent)

If $\mathrm{AA}$ is seen merely as a replacement of White labour with Black labour to redress inequality and injustices, there will be no chance of improving South Africa's competiveness (Bendix, 2010). White labour is, for instance, still needed in South Africa to keep the economy competitive and to train and mentor the young and inexperienced (Bendix, 2007). The following question can be posed: Were provisions put in place in terms of what is to happen to White men and women in obtaining and securing jobs before EE was implemented? Many authors, notably Qunta (1995), have observed that perceptions indeed differ along racial lines. Drawing from these responses, it is evident that White people believe that EE is reverse discrimination, whereas their Black counterparts see it mainly as a corrective measure to undo past wrongs. The stance taken by both White and Black people is understandable, because in the past, White people benefited from education, wealth and comfortable lifestyles.

\section{Theme 2: Loss of employment}

A White male respondent felt demoralised and felt defeated in his attempt to secure employment. According to him,

there are no jobs for white males, so why study or apply for one. If things go from bad to worse, I can always go to Australia to find a job and be part of the "chicken run".

(Respondent) 
According to Anstey (2006, p. 26), the view that EE is detrimental to White people is particularly true, because for many White employees, EE carries the possibility of loss of employment as increasingly more employing organisations seek to adjust the demography of their workforce to reflect efforts in the national transformation process. Anstey (2006, p. 26) goes on to say that jobs are a scarce resource - working hard, performing well and sharing the values of transformation in South Africa may prove to be not as important as race in this transformation process.

\section{Theme 3: The brain drain}

A respondent stated that

owing to employment equity, the country is experiencing skills drainage. Skilled whites are leaving as there are no chances for advancement.

(Respondent)

White people (men in particular) recognise the limits of upward mobility in their organisations, the risks of entering into an unfriendly labour market and their prospects of winning tenders or developing consultancies are constrained without a Black empowerment partnerships (Anstey, 2006). Equity programmes should afford everyone opportunities by ensuring that the skills and potential of personnel are fully utilised. Organisations should be made aware that South Africa is experiencing a brain drain, making it more difficult to find suitable personnel.

The respondents argued that the brain drain in the public service started when voluntary severance packages were introduced in an effort to pave the way for AA candidates to occupy the positions. The public service lost a great deal of skills and expertise, because it did not target specific occupational categories. Many experienced employees left before they could transfer their skills to the incoming incumbents. According to a White male respondent:

Coloureds, Indians and Whites are being left out - they have high qualifications, but more skilled people are leaving the country, because they cannot find jobs.

(Respondent)

Furthermore, respondents expressed their concerns about the skills shortage and responded by stating that this could have a negative impact on the economy. A White male respondent said:

In a developing and emerging economy such as ours, a variety of skills are required. There is currently a brain drain as many professionals have left and this is having a negative effect on the economy. We have to import more skilled people at a cost.

(Respondent)

According to a White female respondent:

Broad-based black economic empowerment has to some extent led to the brain drain as the country has lost many skilled White, Coloured and Indian workers to international companies. What has been done to address this concern? Now even our skilled black resources are leaving for greener shores.

(Respondent)

\section{DISCUSSION}

From research conducted it appears that employees at management level predominantly perceive government as an EE 'watchdog'. Furthermore, reverse discrimination and reverse racism were demarcated as the main areas of concern for nonmanagement employees. The primary attitudes and experiences identified for previously and non-previously disadvantaged groups respectively, included lack of training and development, reverse discrimination, racism and victimisation.

In addition, previously and non-previously disadvantaged groups are experiencing prejudices in the workplace. After 16 years of democracy and the institutionalisation of Employment Equity Act 55 of 1998, these issues have not been resolved These prejudices are specifically coupled with race and gender. Although EE and AA are methods applied to redress the injustices committed under apartheid rule, these methods are experienced negatively by both White people and Black people. They do not seem to be applied consistently in the workplace and are not aligned with specific skills development programmes. The skilled employees indicated that they are 'carrying' those who lack the skills to perform the work required of them.

Another issue that emerged was that the profile of the designated groups, as stipulated in Employment Equity Act 55 of 1998, needs to be revisited. There is also the contentious matter of abolishing Employment Equity Act 55 of 1998 on a specific date, which will give organisations the freedom to implement $\mathrm{EE}$ and $\mathrm{AA}$ on a voluntary basis, as opposed to forcing organisations to comply with legislation.

Considering the attitudes and experience of previously and non-previously disadvantaged groups respectively, it would appear that progress towards achieving EE in South African organisations is not as positive as expected. The results of this research may be valuable for organisations in South Africa which are facing numerous challenges relating to the implementation of EE strategies as well as for organisations where employees experience similar negative attitudes towards EE.

Actions that can be instituted by industrial psychologists in organisations may include, (1) competent and vigorous monitoring of progress towards EE, (2) management taking proactive measures to ensure that the majority of previously disadvantaged and non-previously disadvantaged groups benefit from the legislation and (3) the introduction of holistic human resource management practices that complement target setting. Implementing these measures could overcome the stumbling blocks currently experienced in the (in)effective implementation of EE. At present, the challenge for the management of business organisations is to have a creative vision of fully tapping into the potential of all employees in the workplace. Particularly apt in this context, Sir Winston Churchill, the great British Prime Minister and orator, reminds us to 'leave no man or woman behind' (Maharaj, Ortlepp \& Stacey, 2008).

\section{Recommendations}

Recommendations for future research may be that the results can benefit from contrasting, (1) the perspectives of previously disadvantaged management versus previously advantaged management to (2) the perspectives of previously disadvantaged non-management versus previously advantaged nonmanagement. Furthermore, it will be valuable to include other industries in the private and public sector in future samples. Also, the replication of this study could indicate whether or not the attitudes and experience of employees in South African organisations have shifted from being more negative to positive in terms of the implementation of EE. It can therefore be concluded that the phenomenological approach adopted in this study was ideal for exploring employees' attitudes towards and experiences of EE; however, further research would be beneficial to broaden one's understanding of the implementation of EE.

\section{Possible limitations}

In terms of the interpretation of the results, the following limitations of the study are noted and need to be borne in mind:

- Only 21 organisations were included in the study and may not be representative of all South African organisations.

- Seeing as the sample was determined by the honours industrial and organisational psychology students in terms of convenience, expert judgment and other types of conscious researcher selection, the number of respondents that correspond to the sizes of the participating organisations could not be determined.

- The information provided by respondents constitutes their attitudes and experience of EE in organisations. Employee subjectivity in reporting cannot be excluded (Thomas, 2003). 


\section{REFERENCES}

Anstey, M. (2006). Managing change: Negotiating conflict. Kenwyn: Juta.

Baily, K.D. (1987). Methods of social research. (3rd edn.). London: Free Press.

Bendix, S. (2007). Industrial relations in South Africa. (4th edn.). Cape Town: Juta.

Bendix, S. (2010). Industrial relations in South Africa. (5th edn.). Cape Town: Juta.

Booysen, L. (2007). Barriers to employment equity implementation and retention of blacks in management in South Africa. South African Journal of Labour Relations, 31(1), 47-71.

Charmaz, K. (1995). Grounded theory. In J.A. Smith, R. Harre \& L. van Langenhove (Eds.), Rethinking methods in South Africa (pp. 27-49). Boston: Little Brown

De Beer, J.J., \& Radley, J.H. (2000). A case for managing diversity. Georgeville: Enza.

Denton, M., \& Vloeberghs, D. (2003). Leadership challenges for organizations in the New South Africa. Leadership and Organization Development Journal, 24(2), 84-95.

Department of Labour. (2002). Employment equity register. Retrieved September 21, 2010, from http://www.labour. gov.za/documents/useful-documents/employmentequity/downloads/Useful\%20Document $\% 20-\% 20$ EEA $\% 20-\% 20$ Employment\%20Equity\%20Registry\%202002.pdf

Dickman, J. (1998). Employment equity bill: SACOB's viewpoint. Accountancy SA, July.

Doyle-Bedwell, P. (2008). 'With the appropriate qualifications' - Aboriginal people and employment equity. Canadian Women Studies, 26 (3/4), 77-89.

Ely, M., Anzul, M., Friedman, T., Garner, D., \& McCormack Steinmetz, A. (1990). Doing qualitative research: circles within circles. London: Falmer.

Employment Equity Act 55. (1998). Pretoria: Government Printer.

Erasmus, B.J., Loedolff, P.vZ., Mda, T., \& Nel, P.S. (2007). Managing training and development in South Africa (4th edn.). Cape Town: Oxford University Press.

Esterhuizen, W., \& Martins, N. (2008). Organisational justice and employee responses to employee equity. South African Journal of Labour Relations, 32(2), 66-85.

Field, A.P., \& Morse, J.M. (1985). Nursing research: The application of qualitative approaches. London: Croom Helm.

Fossey, E., Harvey, C., McDermott, F., \& Davidson, L. (2002). Understanding and evaluating qualitative research. Australian and New Zealand Journal of Psychiatry, 36, 717-732.

Guba, E.G. (1981). Criteria for assessing the trustworthiness of naturalistic inquiry, Educational Communication and Technology Journal, 29(2), 75-91.

Guba, E.G., \& Lincoln, Y.S. (1982). Epistemological and methodological bases of naturalistic inquiry, Educational Communication and Technology Journal, 30(4), 233-252.

Guba, E.G., \& Lincoln, Y.S. (1994). Competing paradigms in qualitative research. In N.K. Denzin, \& Y.S.Lincoln (Eds.), Handbook of qualitative research (pp. 105-117). Newbury Park: Sage.

Heilman, M.E., Block, C.J., \& Stathatos, P. (1997). The affirmative action stigma of incompetence: Effects of performance information ambiguity. Academy of Management Journal, 40 (3), 603-625.

Jongens, C. (2006). Perception of employment equity implementation at major South African multi-national financial corporations, Postamble, 2(1), 30-45.

Kruger, D. (1988). An introduction to phenomenological psychology (2nd edn.). Cape Town: Juta.

Kilian, C.M., Hukai, D., \& Mcarty, C.E. (2005). Building diversity in the pipeline to corporate leadership. Journal of Management Development, 24(20), 155-168.

Leonard, A., \& Grobler, A.F. (2006). Exploring challenge to transformational leadership communication about employment equity: Managing organizational change in South Africa. Journal of Communication Management, 10(4), 390-406.
Lincoln Y.S., \& Guba, E.G. (1985). Naturalistic inquiry. Beverly Hills: Sage.

Maharaj, K., Ortlepp, K., \& Stacey, A. (2008). Psychological contracts and employment equity practices. Management Dynamics, 17(1), 16-30.

Mason, G., Williams, G., \& Cranner, S. (2009). Employability skills initiatives in higher education: What effects do they have on graduate labour outcomes? Education Economics, 17(1), 1.

McGown, K.L. (1979). Marketing research. Cambridge: Winthrop.

Morse, J.M., Barrett, M., Mayan, M., Olson, K,, \& Spiers, J. (2002). Verification strategies for establishing reliability and validity in qualitative research. International Journal of Qualitative methods, 1 (2). Retrieved February 12, 2005, from http://www.ualberta.ca/-ijqm/english/engframeset.html.

Nel, P.S., Kirsten, M., Swanepoel, B.J., Erasmus, B.J., \& Poisat, P. (2008). South African employment relations theory and practice. (6th edn.). Pretoria: Van Schaik.

Neuman, W.L. (1994). Social research methods: qualitative and quantitative approaches. Needham Heights: Allyn \& Bacon.

Nevin, T. (2008). Chinese are now black - official. African Business, Aug./Sept., 28-29.

Nienaber, H. (2007). Assessing the management status of South Africa. European Business Review, 19(1), 72-88.

Ng, E.S.W., \& Burke, R.J. (2004). Cultural values as predictors of attitudes towards equality and diversity: A Canadian experience. Woman in Management Review, 19(6), 317-324.

Pietersen, C. (2007). Interpersonal bullying behaviours in the workplace. South African Journal of Industrial Psychology, 33(1), 59-66.

Portnoi, L.M. (2003). Implications of the Employment Equity Act for the higher education sector. South African Journal of Higher Education, 17(2), 79-85.

Qunta, C. (1995). Who's afraid of affirmative action: A survival guide for black professionals. Cape Town: Kwela Books.

Ramgoolam, S. (2005). Experiences of employment equity in the coal mining industry. Unpublished master's dissertation, University of South Africa, Pretoria, Gauteng, South Africa.

Saha, S.K., O'Donnell, D., Patel, T. \& Henegehan, J. (2008). A study of individual values and employment equity in Canada, France and Ireland. Equal Opportunities International, 27(7), 629-645.

Selby, K. \& Sutherland, M. (2006). "Space creation": A strategy for achieving employment equity at senior management level. South African Journal of Labour Relations, 30(2), 36-64.

Strauss, A. \& Corbin, J. (1990). Basics of qualitative research: Grounded theory procedures and techniques. Newbury Park: Sage.

Terre Blanche, M., \& Durrheim, K. (2002). Research in practice: Applied methods for the social sciences. Cape Town: University of Cape Town Press.

Thomas, A. (2002). Employment equity in South Africa: Lessons from the global school. International Journal of Manpower, 23(3), 237-255

Thomas, A. (2003). Employment equity practices at selected companies in South Africa. South African Journal of Labour Relations, 27(3 \& 4), 6-40.

Thomas, A., \& Hlahla, M.A. (2002). Factors that influence the employment of people with disabilities in South Africa. South African Journal of Labour Relations, 26(4), 4-32.

Tougas, F., Beaton, A.M., \& Veilleux, F. (1991). Why women approve affirmative action: The study of a predictor model. International Journal of Psychology, 26,761-776.

Vermeulen, L.P., \& Coetzee, M. (2006). Perceptions of the dimensions of the fairness of affirmative action: A pilot study. South African Journal of Business Management, 37(2), 53-65.

Walters, S.J.K. (2007). Employment equity and affirmative action: An international comparison. Journal of Labor Research, 27(3), 435-437.

Webster, E., \& Von Holdt, K. (2005). Beyond the apartheid workplace: Studies in transition. Scottsville: University of Natal Press. 